\title{
Dermatological changes associated with non-specific inflammatory bowel diseases - Crohn's disease and ulcerative colitis
}

\section{Zmiany skórne w przebiegu nieswoistych zapaleń jelit - choroby Leśniowskiego-Crohna i wrzodziejącego zapalenia jelita grubego}

Agnieszka Hołdrowicz, Anna Woźniacka

Department of Dermatology and Venereology, Medical University of Lodz, Poland

Katedra i Klinika Dermatologii i Wenerologii, Uniwersytet Medyczny w Łodzi, Polska

\author{
CORRESPONDING AUTHOR/ \\ ADRES DO KORESPONDENCJI: \\ lek. Agnieszka Hołdrowicz \\ Katedra i Klinika \\ Dermatologii i Wenerologii \\ Uniwersytet Medyczny w Łodzi \\ plac J. Hallera $1 / 6$ \\ 90-647 Łódź \\ tel.: +48426867981 \\ e-mail: a.holdrowicz@wp.pl
}

\begin{abstract}
Crohn's disease and ulcerative colitis are the most common representatives of non-specific inflammatory bowel diseases. It is a group of chronic diseases of multifactorial and not fully understood aetiology. The characteristic gastro-intestinal symptoms may be accompanied by numerous extraintestinal manifestations. Skin lesions are observed in more than half of patients with inflammatory bowel diseases. Their appearance sometimes precedes development of typical abdominal symptoms. Therefore, the awareness of skin manifestations occurring in the course of inflammatory bowel diseases may contribute to early diagnosis and implementation of therapy.
\end{abstract}

\section{STRESZCZENIE}

Choroba Leśniowskiego-Crohna i wrzodziejące zapalenie jelita grubego są najczęściej występującymi chorobami z grupy nieswoistych zapaleń jelit. Jest to grupa chorób przewlekłych o wieloczynnikowej i nie do końca poznanej etiologii, w przebiegu których poza charakterystycznymi objawami ze strony przewodu pokarmowego obserwuje się również liczne manifestacje pozajelitowe. Zmiany skórne stwierdza się u ponad połowy chorych na nieswoiste zapalenia jelit, a ich pojawienie się niekiedy poprzedza typowe objawy brzuszne. W związku z powyższym znajomość przez lekarzy klinicystów zmian skórnych występujących w przebiegu nieswoistych zapaleń jelit jest kluczowa i może się przyczynić do przeprowadzenia prawidłowej diagnostyki oraz wczesnego wdrożenia odpowiedniej terapii.

Key words: Crohn's disease, extraintestinal manifestations, ulcerative colitis.

Słowa kluczowe: choroba Leśniowskiego-Crohna, manifestacje pozajelitowe, wrzodziejące zapalenie jelita grubego. 


\section{INTRODUCTION}

Crohn's disease and ulcerative colitis are the most common representatives of the group of diseases known as non-specific inflammatory bowel diseases (IBD). Regardless of characteristic symptoms from the gastrointestinal tract, there are also extraintestinal complications occurring in these diseases, including changes of the skin and mucosa, which may be an important diagnostic marker, preceding typical abdominal symptoms. The literature distinguishes a number of genetic $[1,2]$, clinical and epidemiological $[3,4]$ factors affecting the risk of skin lesions in the course of IBD. Roth et al. showed that extraintestinal symptoms in the form of pyoderma gangrenosum, erythema nodosum and aphthous stomatitis appeared more often in young women with high activity of the underlying disease, assessed using the Crohn's Disease Activity Index (CDAI) and Modified Truelove and Witts Activity Index (MTWAI). In the above-mentioned study, it was proved that patients with one of the above three skin manifestations were younger at the time of developing IBD than patients with no such lesions. A clear relationship was also demonstrated between the above-mentioned skin changes and the familial form of Crohn's disease. However, no such relationship was found for patients with ulcerative colitis [3]. The data available in the literature are inconsistent in this respect - Ampuero et al. failed to demonstrate existence of that kind of correlation for any familial form of IBD $[3,4]$.

The incidence of skin lesions in the course of IBD ranges from $2 \%$ to $53 \%$, depending on the methodology adopted. They are one of the most common extraintestinal symptoms of the disease [5]. Among skin manifestations occurring in IBD there are specific changes caused by the granulomatous inflammatory process, reactive changes, lesions resulting from the applied treatment and changes related to the deficiency of vitamins, micro- and macroelements [5, 6]. Dermatoses more common in the population of people with IBD constitute a separate group. These are, among others bullous pemphigoid, hidradentitis suppurative, dermatitis herpetiformis, psoriasis, scleroderma, lichen planus, epidermolysis bullosa acquisita, urticaria, systemic lupus erythematosus, secondary amyloidosis and vitiligo [5-7].

\section{SPECIFIC SKIN CHANGES}

They occur in the course of Crohn's disease and are characterized by histopathological presentation of skin and mucosa typical for the underlying disease. They are located in the perianal or periostomy area, resulting from the spread of the inflammatory

\section{WPROWADZENIE}

Choroba Leśniowskiego-Crohna oraz wrzodziejące zapalenie jelita grubego są najczęstszymi przedstawicielami grupy chorób określanej jako nieswoiste zapalenia jelit (NZJ). Niezależnie od charakterystycznych objawów ze strony przewodu pokarmowego u pacjentów z tymi schorzeniami stwierdza się również występowanie powikłań pozajelitowych, w tym zmian w obrębie skóry i błony śluzowej, które mogą stanowić istotny marker diagnostyczny, poprzedzając typowe objawy brzuszne. W piśmiennictwie wyróżniono szereg czynników genetycznych [1, 2], klinicznych i epidemiologicznych [3, 4] wpływających na ryzyko wystąpienia zmian skórnych w przebiegu NZJ. Roth i wsp. wykazali, że objawy pozajelitowe $\mathrm{w}$ postaci piodermii zgorzelinowej, rumienia guzowatego i aftowego zapalenia jamy ustnej pojawiają się częściej u młodych kobiet z dużą aktywnością choroby podstawowej ocenianą przy użyciu skali CDAI (Crohn's Disease Activity Index) oraz zmodyfikowanej skali Truelove'a i Wittsa (Modified Truelove and Witts Activity Index - MTWAI). W badaniu tym okazało się, że pacjenci, u których stwierdzono jedną z 3 powyższych manifestacji skórnych, byli młodsi w momencie zachorowania na NZJ niż osoby, u których tych zmian nie stwierdzono. Wykazano również wyraźny związek powyższych zmian z rodzinną postacią choroby Leśniowskiego-Crohna. Zależności takiej nie stwierdzono jednak u pacjentów $\mathrm{z}$ wrzodziejącym zapaleniem jelita grubego [3]. Dostępne w piśmiennictwie dane są niespójne w tej kwestii - w badaniu przeprowadzonym przez Ampuero i wsp. nie udało się wykazać takiej zależności dla żadnej rodzinnej postaci NZJ $[3,4]$.

Częstość występowania zmian skórnych w przebiegu NZJ waha się w szerokim zakresie od 2\% do $53 \%$ w zależności od przyjętej metodologii badania. Stanowią one jeden z najczęstszych objawów pozajelitowych choroby [5]. Wśród manifestacji skórnych występujących w przebiegu NZJ można wyróżnić swoiste zmiany wywołane przez ziarniniakowy proces zapalny, zmiany reaktywne, wykwity powstające pod wpływem zastosowanego leczenia oraz zmiany związane $z$ niedoborem witamin oraz mikro- i makroelementów [5, 6]. Oddzielną grupę stanowią dermatozy wyraźnie częściej występujące u osób z NZJ. Są to m.in. pemfigoid pęcherzowy, ropnie mnogie pach, opryszczkowate zapalenie skóry, łuszczyca, twardzina, liszaj płaski, nabyte pęcherzowe oddzielanie się naskórka, pokrzywka, toczeń rumieniowaty układowy, wtórna amyloidoza i bielactwo [5-7].

\section{SWOISTE ZMIANY SKÓRNE}

Swoiste zmiany skórne występują w przebiegu choroby Leśniowskiego-Crohna i charakteryzują się obecnością w badaniu histopatologicznym bioptatów 
process from the gastrointestinal tract. These include perianal and enterocutaneous fistulas, fissures, ulcers and abscesses. Specific lesions also include eruptions in the mouth and face, e.g. swelling of the mucosa of the cheeks, infiltrative changes in the lips, swelling of the lips, cracks within the mouth and tongue, a "cobblestone" appearance of the oral mucosa, gingival hyperplasia, linear ulcers, orofacial granulomatosis. It should also be noted that the autoimmune process in patients suffering from Crohn's disease may involve minor salivary glands, causing the feeling of dry mouth [6-9]. Metastatic form of Crohn's disease, consisting in the presence of skin lesions not related to the gastrointestinal tract, in which non-caseating granulomas are found in the histopathological image is a rare representative of this group of pathologies. It is much more common in adults, mainly in the age of 29-39. In 1/5 of cases it may precede development of abdominal symptoms. These are usually papules, nodules, pustules, infiltrates, erosions, ulcers, abscesses and fistulas, which are preceded by the appearance of erythematous-oedematous changes at the initial stage of the disease. Differential diagnosis is often very difficult as these changes may resemble a number of more common dermatoses. Skin lesions are most often located on limbs, trunk, face and in skin folds. In children these lesions are more often found in the genitals, and they are usually oedematous or oedematous-erythematous. Moreover, fissures and ulcers may also develop $[6,7,10,11]$.

\section{REACTIVE SKIN LESIONS}

Antigens common to the skin and intestinal bacteria stimulate the immune system, leading to reactive skin lesions $[5,11]$. Among them, bowel-associated dermatosis-arthritis syndrome (BADAS), polyarteritis nodosa, pyoderma gangrenosum, erythema nodosum, Sweet's syndrome, necrotizing vasculitis, leukocytoclastic vasculitis, pyoderma vegetans, pyostomatitis vegetans and recurrent aphthous stomatitis. The most common representatives of this group include erythema nodosum, pyoderma gangrenosum and recurrent aphthous stomatitis [5, 11, 12].

\section{Erythema nodosum}

Erythema nodosum is the most common skin manifestation that occurs in the course of IBD, more often found in patients with Crohn's disease, especially in young women in the active phase of the disease $[13,14]$. The incidence of coexistence of this dermatosis with Crohn's disease ranges from $4 \%$ to $15 \%$. Slightly less frequently erythema nodosum accompanies ulcerative colitis, affecting approx. $1-10 \%$ of this group of patients $[14,15]$. There is probably skóry oraz błony śluzowej obrazu typowego dla choroby podstawowej. Zlokalizowane są w okolicy okołoodbytniczej lub okołostomijnej i powstają wskutek szerzenia się procesu zapalnego z przewodu pokarmowego. Należą do nich przetoki okołoodbytowe oraz skórno-jelitowe, szczeliny, owrzodzenia i ropnie. Do swoistych zmian zalicza się także wykwity obecne w obrębie jamy ustnej i twarzy, takie jak obrzęk błony śluzowej policzków, zmiany naciekowe warg, obrzęk warg, pęknięcia w obrębie ust i języka, objaw „brukowania” błony śluzowej jamy ustnej, hiperplazja dziąseł, linijne owrzodzenia, zmiany ziarniniakowe jamy ustnej i twarzy. Należy również zauważyć, że proces autoimmunologiczny u pacjentów z chorobą Leśniowskiego-Crohna może zajmować małe gruczoły ślinowe, czemu towarzyszy uczucie suchości w jamie ustnej [6-9]. Rzadkim przedstawicielem tej grupy jest przerzutowa postać choroby Leśniowskiego-Crohna polegająca na obecności zmian skórnych o lokalizacji niezwiązanej z przewodem pokarmowym, w których obrazie histopatologicznym stwierdza się nieserowaciejące ziarniniaki. Występuje ona zdecydowanie częściej u dorosłych, przede wszystkim w wieku 2939 lat. W 1/5 przypadków może poprzedzać objawy brzuszne. Są to najczęściej zmiany w postaci grudek, guzków, krostek, nacieków, nadżerek, owrzodzeń, ropni i przetok, które poprzedzone są występowaniem zmian rumieniowo-obrzękowych w początkowej fazie choroby. Diagnostyka róźnicowa może być bardzo trudna, gdyż zmiany mają tendencję do upodabniania się do wielu częściej występujących dermatoz. Zwykle lokalizują się na kończynach, tułowiu, twarzy oraz w fałdach skórnych. W populacji dziecięcej częściej niż u dorosłych zmiany występują na narządach płciowych i mają typowo charakter obrzękowy lub obrzękowo-rumieniowy. Mogą ponadto występować szczeliny i owrzodzenia $[6,7,10,11]$.

\section{REAKTYWNE ZMIANY SKÓRNE}

Antygeny wspólne dla skóry i bakterii bytujących $\mathrm{w}$ jelicie pobudzają układ immunologiczny, co prowadzi do powstania reaktywnych zmian skórnych [5, 11]. Wśród nich można wymienić: zapalenie stawów wywołane jelitowym zespoleniem omijającym (bowel-associated dermatosis-arthritis syndrome - BADAS), guzkowe zapalenie tętnic, piodermię zgorzelinową, rumień guzowaty, zespół Sweeta, martwicze zapalenie naczyń, leukocytoklastyczne zapalenie naczyń, piodermię bujającą, ropne przerostowe zapalenie jamy ustnej i nawracające aftowe zapalenie jamy ustnej. Do najczęściej występujących zalicza się: rumień guzowaty, piodermię zgorzelinową oraz nawracające aftowe zapalenie jamy ustnej $[5,11,12]$. 
a genetic predisposition that increases the risk of erythema nodosum in some patients with IBD. The association of this dermatosis has been demonstrated with the presence of HLA B27, Rs33980500 (in the case of Crohn's disease), Rs13190932, Rs13196377 (in the case of colitis ulcerosa) variants of the TRAF3IP2 allele and the $-1031 \mathrm{C}$ polymorphism of the TNF-a gene in the population of people with IBD. The coexistence of both diseases is also related to the presence of ANCA antibodies (anti-neutrophil cytoplasmic antibodies) $[2,13,15]$. Erythema nodosum manifests itself as painful, inflammatory, subcutaneous tumors, several $\mathrm{cm}$ in diameter that resolve without leaving a scar. The most common location of lesions is the surface of forearms, lower legs and thighs. It should also be noted that skin changes may be accompanied by general symptoms such as weakness, articular pain and fever $[13,14,16]$. The severity of skin symptoms usually correlates with the severity of the underlying disease, and is independent of it only in $10 \%$ of cases [11]. Effective treatment of IBD usually leads also to the resolution of skin lesions, however, sometimes there is a need for systemic glucocorticosteroidotherapy, and in some cases for the treatment with azathioprine or anti-TNF-a antibodies [14, 16].

\section{Pyoderma gangrenosum}

Pyoderma gangrenosum belongs to the group of neutrophilic inflammatory diseases, the common feature of which is the presence of a sterile neutrophilic infiltrate, which may involve the epidermis, dermis and subcutaneous tissue, and sometimes also other organs - the greatest number of cases in such localization described so far concerned lung and joint involvement. There are no clear criteria for the diagnosis of the disease, and diagnosis is based on the elimination of other possible causes of skin changes. In each case, it is advisable to perform a biopsy in order to exclude another aetiology, and the collected material should include the bottom and edge of the ulcer. Lesions are the most commonly located in lower limbs. In children the head and neck are also often affected, whereas in infants the anogenital area could be involved. The clinical presentation and the rate of spreading of the lesions are variable, and therefore diagnostic errors are common. Correct diagnosis is particularly difficult in cases where organ changes are the first to appear. There are several clinical forms of the disease, including ulcerative, drug-induced, pustular, bullous, vegetans, or postoperative form. Postoperative, periostomy, ulcerative and pustular pyoderma are the most commonly found in patients with IBD. The ulcerative form is characterized by formation of peripherally spreading ulcers of various sizes ranging from a few millimeters to several dozen centimeters

\section{Rumień guzowaty}

Rumień guzowaty jest najczęstszą manifestacją skórną pojawiającą się w przebiegu NZJ, stwierdzaną częściej $\mathrm{u}$ pacjentów $\mathrm{z}$ chorobą Leśniowskiego-Crohna, przede wszystkim młodych kobiet w aktywnej fazie choroby $[13,14]$. Częstość współwystępowania tej dermatozy z chorobą Leśniowskiego-Crohna waha się w zakresie 4-15\%. Nieco rzadziej rumień guzowaty towarzyszy wrzodziejącemu zapaleniu jelita grubego, dotyczy ok. $1-10 \%$ tej grupy pacjentów $[14,15]$. Prawdopodobnie istnieje predyspozycja genetyczna zwiększająca ryzyko rozwoju rumienia guzowatego u części chorych z NZJ. Wykazano związek tej dermatozy m.in. z obecnością HLA B27, wariantów Rs33980500 (w przypadku choroby Leśniowskiego-Crohna), Rs13190932, Rs13196377 (w przypadku colitis ulcerosa) allela TRAF3IP2 oraz polimorfizmu -1031C genu TNF-a u osób z NZJ. Współwystępowanie obu jednostek chorobowych ma także związek z obecnością przeciwciał ANCA (anti-neutrophil cytoplasmic antibodies) $[2,13,15]$. Rumień guzowaty manifestuje się w postaci bolesnych, zapalnych, podskórnych guzów o średnicy kilku centymetrów, ustępujących bez pozostawienia blizny. Zmiany najczęściej lokalizują się na powierzchni przedramion, podudzi oraz ud. Należy również zauważyć, że wykwitom mogą towarzyszyć objawy ogólne, takie jak osłabienie, ból stawów i gorączka [13, $14,16]$. Nasilenie dolegliwości skórnych zwykle koreluje z nasileniem choroby podstawowej, a tylko w $10 \%$ przypadków jest od niej niezależne [11]. Skuteczne leczenie NZJ prowadzi najczęściej do ustąpienia zmian skórnych, jednak niekiedy konieczne jest zastosowanie ogólnej glikokortykosteroidoterapii, a w niektórych przypadkach azatiopryny lub przeciwciał anty-TNF-a $[14,16]$.

\section{Piodermia zgorzelinowa}

Piodermia zgorzelinowa należy do grupy neutrofilowych chorób zapalnych, których cechą wspólną jest obecność jałowego nacieku neutrofilowego mogącego obejmować naskórek, skórę właściwą i tkankę podskórną, a czasem również inne narządy - do tej pory najwięcej opisanych przypadków tego typu lokalizacji dotyczyło zajęcia płuc i stawów. Nie istnieją jednoznaczne kryteria rozpoznania choroby, a diagnoza opiera się na wyeliminowaniu pozostałych możliwych przyczyn zmian skórnych. W każdym przypadku wskazane jest wykonanie biopsji w celu wykluczenia innej etiologii, a pobrany materiał powinien obejmować dno i brzeg owrzodzenia. Najczęstsza lokalizacja zmian to kończyny dolne. U dzieci często zajmowana jest również głowa i szyja, a u niemowląt okolica anogenitalna. Obraz kliniczny i tempo szerzenia się zmian są zróżnicowane, w związku z czym często dochodzi do pomyłek diagnostycznych. Postawienie właściwej diagnozy jest szczególnie trudne w przypadkach, w których jako pierwsze pojawią się zmiany narządowe. Wyróżnia się kilka postaci klinicznych choroby, m.in. postać wrzo- 
in diameter. Typical skin lesions are most often preceded by the appearance of a small blue-red pimple resulting from a pathergy following a minor injury. The lesion then disintegrates usually to form some rapidly spreading ulcers, sometimes very deep. The bottom of the ulcer may be filled with purulent contents, necrotic tissues or granulation tissue. The edge of the lesion is usually raised and surrounded by a bluish-erythematous border. It is possible for several separate changes to occur simultaneously. Changes are usually accompanied by severe pain, fever and general weakness. One form of pyoderma gangrenosum is the postoperative form, characterized by the formation of an ulcer at the site of surgical wound. It most often occurs after thoracic surgery. This location of lesions often raises the suspicion of bacterial infection of the postoperative wound and hinders the correct diagnosis. Another form of the disease is pustular pyoderma, characterized by the presence of inflammatory pustules that disintegrate and form shallow ulcers. Currently, the recommended first line of treatment is prednisone, and in cases resistant to steroid therapy, cyclosporine. The lesions heal with scarring, and the mortality in pyoderma gangrenosum reaches $16 \%[17,18]$.

\section{Sweet's syndrome}

Sweet's syndrome, next to pyoderma gangrenosum, belongs to the group of neutrophilic diseases. It is more common in women, especially between the age of 30 and 60. The relationship of Sweet's syndrome with IBD has been repeatedly documented in the literature in the form of numerous case reports. Inflammatory bowel disease is considered to be the third most common group of diseases associated with Sweet's syndrome, although it is very difficult to establish the frequency of coexistence of both diseases due to the rare occurrence of this dermatosis [8, 19].

Skin lesions are clearly demarcated, raised, painful, intensely red, swollen papules, nodules and plaques of various sizes in an asymmetrical arrangement. They can be located all over the body but usually occupy the upper torso, arms, neck and face. Lower limb eruptions may resemble erythema nodosum, and differential diagnosis is sometimes very difficult. The appearance of skin lesions is usually preceded or occurs simultaneously with flu-like symptoms, such as weakness, fever, headache and articular pain. The mucosa is rarely affected and changes in this location require differentiation from Candida infection. A special form of Sweet's syndrome is the bullous form, in which blisters, filled with blood or serous content, dominate. After their rupture, superficial ulcerations may form [18-20]. As in pyoderma gangrenosum, neutrophilic infiltrates are sometimes present in in- dziejącą, indukowaną lekami, krostkową, pęcherzową, bujającą i pooperacyjną. U chorych z NZJ najczęściej stwierdza się piodermię zgorzelinową pooperacyjną, okołostomijną, wrzodziejącą oraz krostkową. Postać wrzodziejąca charakteryzuje się powstawaniem szerzącego się obwodowo owrzodzenia różnej wielkości, o średnicy od kilku milimetrów do kilkudziesięciu centymetrów. Charakterystyczne zmiany skórne najczęściej poprzedza pojawienie się niewielkiej, niebiesko-czerwonej krostki, będącej objawem patergii i powstającej pod wpływem drobnego urazu. Następnie zmiana rozpada się, tworząc zwykle szybko szerzące się, niekiedy bardzo głębokie owrzodzenie. Dno owrzodzenia może być wypełnione treścią ropną, tkankami martwiczymi lub ziarniną. Brzeg zmiany jest zwykle uniesiony i otoczony błękitno-rumieniową obwódką. Możliwe jest występowanie kilku ognisk jednocześnie. Zmianom towarzyszą na ogół silne dolegliwości bólowe, gorączka i ogólne osłabienie. Jedną z postaci piodermii zgorzelinowej jest postać pooperacyjna, charakteryzująca się powstawaniem owrzodzenia w miejscu rany. Najczęściej występuje po zabiegach chirurgicznych w obrębie klatki piersiowej. Lokalizacja zmian często budzi podejrzenie powikłania zakażeniem bakteryjnym rany pooperacyjnej, co utrudnia postawienie właściwej diagnozy. Inną postacią choroby jest piodermia krostkowa charakteryzująca się obecnością zapalnych krost, które rozpadają się i tworzą płytkie owrzodzenia. Obecnie rekomendowanym leczeniem pierwszego wyboru jest terapia prednizonem, a w przypadkach opornych na glikokortykosteroidoterapię - cyklosporyną. Zmiany goją się z pozostawieniem blizn, a śmiertelność w przebiegu piodermii zgorzelinowej sięga 16\% [17, 18].

\section{Zespół Sweeta}

Zespół Sweeta, obok piodermii zgorzelinowej, należy do grupy chorób neutrofilowych. Częściej występuje u kobiet, szczególnie między 30. a 60. rokiem życia. Związek zespołu Sweeta z NZJ został wielokrotnie potwierdzony w piśmiennictwie w postaci licznych opisów przypadków. Nieswoiste zapalenia jelit uważane są za trzecią najczęstszą grupę chorób związanych z zespołem Sweeta, jednak ustalenie częstości współistnienia obu jednostek jest bardzo trudne ze względu na rzadkość występowania tej dermatozy $[8,19]$.

Zmiany skórne mają postać wyraźnie odgraniczonych, uniesionych, bolesnych, intensywnie czerwonych, obrzękowych grudek, guzków i blaszek różnej wielkości o układzie asymetrycznym. Mogą być zlokalizowane na całej skórze, ale zwykle zajmują górną część tułowia, kończyny górne, szyję i twarz. Wykwity zlokalizowane na kończynach dolnych mogą przypominać rumień guzowaty, a diagnostyka różnicowa niekiedy jest bardzo trudna. Pojawienie się zmian skórnych zwykle jest poprzedzone lub występuje jednocześnie z objawami grypopodobnymi, takimi jak osłabienie, 
ternal organs. An important role in making the diagnosis is skin biopsy, which shows dense, diffuse, perivascular neutrophilic infiltrates, leukocytoclasia, swelling of the papillary layer, sometimes with subepidermal blisters, and no clear signs of vasculitis [18, 21]. In laboratory tests, neutrophilia and elevated inflammatory markers are characteristic. The mainstay of treatment is local and systemic steroid therapy, usually resulting in rapid improvement $[18,19]$.

\section{Aphthous stomatitis}

The disease occurs in $5-10 \%$ of patients with Crohn's disease, although according to some sources it may affect up to $1 / 3$ of patients $[11,21]$. It is the most common parenteral manifestation found in the mucosa of patients with IBD [21]. In patients with ulcerative colitis, the incidence of aphthous stomatitis is lower, but the disease may affect up to $10 \%$ of this population. Moreover, it has been shown that aphthous stomatitis is more common in people with other extraintestinal manifestations [22]. Single or multiple erosions and ulcers are characteristic of this disease. Lesions are surrounded by an inflammatory border, and there is usually a white fibrin coating on their bottom. The diagnosis is most often made on the basis of the clinical presentation. Biopsy is indicated in the case of long-lasting lesions, mainly in smokers, due to the increased risk of squamous cell carcinoma of the mucosa in this group of patients [21]. Treatment primarily targets the underlying disease and is usually sufficient. It is possible to use additional local treatment in the form of NSAIDs, local anesthetics, eg lidocaine and glucocorticosteroid preparations [21, 22].

\section{SKIN CHANGES RELATED TO THE DEFICIENCY OF VITAMINS, MICRO- AND MACROELEMENTS}

Deficiency of vitamins, micro- and macroelements is a common complication developing in course of IBD. The prevalence of malnutrition in this group of patients ranges from $12 \%$ to $85 \%$, depending on the characteristics of the study group [23]. The problem of malnutrition among patients with IBD results, among others, from malabsorption associated with the involvement of a significant part of the small intestine or resection of its fragment, increased demand for nutrients and chronic, often bloody diarrhoea [24]. Moreover, a significant proportion of patients limit their own consumption of various types of food, fearing exacerbation of the disease $(75 \%$ of respondents) or aggravation of its symptoms ( $87 \%$ of respondents). It has been shown that the tendency to reduce consumption of various nutritional products affects patients with Crohn's disease more often than gorączka, bóle głowy i stawów. Błona śluzowa rzadko jest zajęta, a zmiany w tej lokalizacji wymagają różnicowania z zakażeniem drożdżakowym. Szczególną postacią zespołu Sweeta jest postać pęcherzowa, w której pęcherze wypełnione treścią krwistą lub surowiczą są wykwitami dominującymi. Po ich pęknięciu mogą tworzyć się powierzchowne owrzodzenia [18-20]. Podobnie jak w piodermii zgorzelinowej nacieki neutrofilowe obecne są niekiedy w obrębie narządów wewnętrznych. W diagnostyce ważną rolę odgrywa badanie histopatologiczne wycinka skóry, w którym stwierdza się gęste, rozsiane, okołonaczyniowe nacieki neutrofilowe, leukocytoklazję, obrzęk warstwy brodawkowatej, niekiedy z występowaniem podnaskórkowych pęcherzy oraz brak wyraźnych cech zapalenia naczyń $[18,21]$. $\mathrm{W}$ badaniach laboratoryjnych charakterystyczna jest neutrofilia oraz zwiększone wartości markerów stanu zapalnego. Podstawę leczenia stanowi miejscowa i ogólna glikokortykosteroidoterapia, po której zazwyczaj następuje szybka poprawa $[18,19]$.

\section{Aftowe zapalenie jamy ustnej}

Występuje u 5-10\% pacjentów z chorobą Leśniowskiego-Crohna, choć według niektórych źródeł może dotyczyć nawet $1 / 3$ chorych [11, 21]. Jest najczęstszą manifestacją pozajelitową stwierdzaną na błonie śluzowej pacjentów z NZJ [21]. U chorych na wrzodziejące zapalenie jelita grubego częstość występowania aftowego zapalenia jamy ustnej jest mniejsza, ale może dotyczyć nawet do $10 \%$ tej populacji. Ponadto wykazano, że aftowe zapalenie jamy ustnej częściej stwierdza się u osób z innymi manifestacjami pozajelitowymi [22]. Pojedyncze lub mnogie nadżerki i owrzodzenia są charakterystyczne dla tej jednostki chorobowej. Zmiany otoczone są zapalną obwódką, a na ich dnie znajduje się zwykle biały, włóknikowy nalot. Rozpoznanie ustala się najczęściej na podstawie obrazu klinicznego. Biopsja wskazana jest w przypadku długo utrzymujących się zmian, głównie u palaczy tytoniu ze względu na zwiększone ryzyko występowania w tej grupie raka kolczystokomórkowego błony śluzowej [21]. Leczenie dotyczy przede wszystkim choroby podstawowej i zazwyczaj jest wystarczające. Możliwe jest stosowanie dodatkowo terapii miejscowej w postaci niesteroidowych leków przeciwzapalnych, środków miejscowo znieczulających, np. lidokainy, oraz preparatów glikokortykosteroidowych [21, 22].

\section{ZMIANY SKÓRNE ZWIAZZANE Z NIEDOBOREM WITAMIN ORAZ MIKRO- I MAKROELEMENTÓW}

Niedobory witamin oraz mikro- i makroelementów są często występującym powikłaniem w przebiegu NZJ. Częstość niedożywienia w tej grupie pacjentów waha się w szerokim zakresie od $12 \%$ do $85 \%$ w zależności od specyfiki grupy badanej [23]. Problem 
those with ulcerative colitis, but no discrepancy in the incidence of malnutrition in patients with these forms of IBD was found. In most cases malnutrition correlates with IBD activity, but it can also occur in people in remission and in patients with the disease of moderate severity [23, 24].

Vitamin, micro- and macroelement deficiencies lead to a number of changes in the skin, mucosa, hair and nails. Table 1 shows the symptoms of deficiency of selected nutrients [25-39].

\section{SKIN LESIONS ASSOCIATED WITH THE TREATMENT OF INFLAMMATORY BOWEL DISEASES}

A number of skin lesions occurring in people with IBD are the result of treatment, and it is very niedożywienia wśród chorych z NZJ wynika m.in. $\mathrm{z}$ upośledzonego wchłaniania związanego z zajęciem znacznej części jelita cienkiego lub resekcją jego fragmentu, zwiększonego zapotrzebowania na składniki odżywcze i przewlekłych, często krwistych biegunek [24]. Ponadto znaczna część pacjentów samodzielnie ogranicza spożywanie różnego rodzaju pokarmów, obawiając się wywołania zaostrzenia choroby (75\% badanych) lub nasilenia jego objawów (87\% badanych). Wykazano, że tendencja do ograniczania spożycia różnych produktów żywieniowych dotyczy częściej pacjentów z chorobą Leśniowskiego-Crohna niż colitis ulcerosa, ale nie udało się stwierdzić rozbieżności w częstości występowania niedożywienia u chorych z tymi postaciami NZJ. Niedożywienie w większości przypadków koreluje z aktywnością NZJ, ale może

Table I. Clinical manifestations in the course of deficiency of vitamins, micro- and macronutrients

Tabela I. Zmiany kliniczne w przebiegu niedoboru wybranych witamin oraz mikro- i makroelementów

\begin{tabular}{|c|c|c|c|c|}
\hline $\begin{array}{l}\text { Vitamins and } \\
\text { microelements/ } \\
\text { Witaminy } \\
\text { i mikroelementy }\end{array}$ & Skin manifestations/Objawy skórne & $\begin{array}{c}\text { Oral and conjunctival } \\
\text { manifestations/Objawy } \\
\text { w obrębie jamy ustej } \\
\text { i spojówek }\end{array}$ & Hair/Włosy & $\begin{array}{c}\text { Nails/ } \\
\text { Paznokcie }\end{array}$ \\
\hline $\begin{array}{l}\text { Vitamin A } \\
{[9,25,26] /} \\
\text { Witamina A } \\
{[9,25,26]}\end{array}$ & $\begin{array}{l}\text { Hyperkeratosis of hair follicles/Hiperkeratoza mieszków } \\
\text { włosowych } \\
\text { Phrynoderma/Frynodermia }\end{array}$ & $\begin{array}{l}\text { Dry eye syndrome/Zespół } \\
\text { suchego oka } \\
\text { Oral dryness/Suchość jamy ustnej } \\
\text { Angular cheilitis/Zapalenie } \\
\text { kącików ust } \\
\text { Atrophy of oral mucosa/Atrofia } \\
\text { błony śluzowej jamy ustnej }\end{array}$ & & \\
\hline
\end{tabular}

\begin{tabular}{|c|c|}
\hline 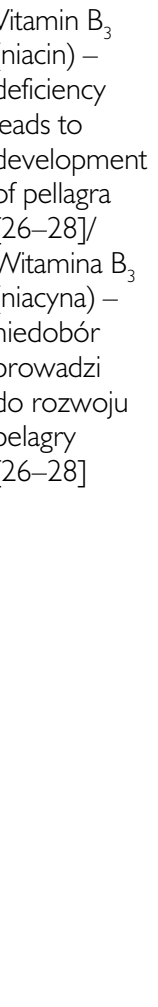 & $\begin{array}{l}\text { Well-demarcated erythematous-oedematous lesions } \\
\text { symmetrically located in the skin exposed to light/Dobrze } \\
\text { odgraniczone zmiany rumieniowo-obrzękowe } \\
\text { o symetrycznej lokalizacji w obrębie skóry eksponowanej } \\
\text { na światło } \\
\text { There may be blisters and vesicles that rupture leaving } \\
\text { erosions/Mogą występować pęcherze i pęcherzyki, } \\
\text { po których pęknięciu pojawiają się nadżerki } \\
\text { In the later stage of the disease, lichenification and } \\
\text { hyperpigmentation of the skin appear/W późniejszej fazie } \\
\text { choroby pojawia się lichenifikacja i hiperpigmentacja skóry } \\
\text { Skin lesions are accompanied by itching/Zmianom skórnym } \\
\text { towarzyszy świąd } \\
\text { The first skin lesions usually appear on the dorsal surfaces } \\
\text { of the hands/Pierwsze zmiany skórne pojawiają się zwykle } \\
\text { na grzbietowych powierzchniach rąk } \\
\text { The sandal sign - no skin changes on the surface of the foot } \\
\text { covered by shoes/Objaw sandała - brak zmian skórnych } \\
\text { na powierzchni stopy zakrytej przez but } \\
\text { Butterfly sign - butterfly-shaped erythema on the nose } \\
\text { and cheeks/Objaw motyla - rumień w kształcie motyla } \\
\text { zlokalizowany na nosie i policzkach } \\
\text { Casal's necklace - erythema on the neck/Objaw naszyjnika } \\
\text { casala - rumień zlokalizowany na szyi } \\
\text { Sometimes they may be accompanied by fissures in the } \\
\text { hands and feet/Niekiedy mogą towarzyszyć pęknięcia } \\
\text { w obrębie dłoni i stóp } \\
\text { Chronic course with periods of exacerbation and remission/ } \\
\text { Przebieg przewlekły z okresami zaostrzeń i remisji }\end{array}$ \\
\hline
\end{tabular}

Glossitis/Zapalenie języka

Stomatitis/Zapalenie jamy ustnej 
Table I. Cont.

Tabela I. Cd.

\begin{tabular}{|c|c|c|c|c|}
\hline $\begin{array}{l}\text { Vitamins and } \\
\text { microelements/ } \\
\text { Witaminy } \\
\text { i mikroelementy }\end{array}$ & Skin manifestations/Objawy skórne & $\begin{array}{c}\text { Oral and conjunctival } \\
\text { manifestations/Objawy } \\
\text { w obrębie jamy ustej } \\
\text { i spojówek }\end{array}$ & Hair/Włosy & $\begin{array}{c}\text { Nails/ } \\
\text { Paznokcie }\end{array}$ \\
\hline $\begin{array}{l}\text { Vitamin } B_{6}[26] / \\
\text { Witamina } B_{6} \\
{[26]}\end{array}$ & $\begin{array}{l}\text { Seborrheic dermatitis/tojotokowe zapalenie skóry } \\
\text { Impaired conversion of tryptophan to niacin as a result of } \\
\text { severe vitamin } B_{6} \text { deficiency may lead to development of } \\
\text { pellagra symptoms/Upośledzenie przekształcania tryptofanu } \\
\text { do niacyny w wyniku ciężkiego niedoboru witaminy } B_{6} \\
\text { może prowadzić do rozwoju objawów pelagry } \\
\text { Skin paleness/Bladość skóry }\end{array}$ & $\begin{array}{l}\text { Stomatitis/Zapalenie jamy ustnej } \\
\text { Glossitis/Zapalenie języka } \\
\text { Cheilitis/Zapalenie czerwieni } \\
\text { wargowej } \\
\text { Paleness of mucosa/Bladość } \\
\text { błony śluzowej }\end{array}$ & & \\
\hline $\begin{array}{l}\text { Vitamin } \mathrm{B}_{7} \\
\text { (vitamin } \mathrm{H}_{1} \\
\text { biotin) }[26,29, \\
\text { 30]/ Witamina } \\
\mathrm{B}_{7} \text { (witamina } \mathrm{H}, \\
\text { biotyna) }[26, \\
29,30]\end{array}$ & $\begin{array}{l}\text { Dermatitis located mainly on the face/Zmiany wypryskowe } \\
\text { zlokalizowane przede wszystkim na twarzy } \\
\text { Seborrheic dermatitis/Lojotokowe zapalenie skóry } \\
\text { Increased risk of skin infections/Zwiększone ryzyko infekcji } \\
\text { skórnych } \\
\text { Abnormal distribution of adipose tissue within the face/ } \\
\text { Nieprawidłowa dystrybucja tkanki tłuszczowej w obrębie } \\
\text { twarzy }\end{array}$ & $\begin{array}{l}\text { Conjunctivitis/Zapalenie } \\
\text { spojówek }\end{array}$ & $\begin{array}{l}\text { Alopecia/ } \\
\text { Łysienie } \\
\text { Hair thinning/ } \\
\text { Ścieńczenie } \\
\text { włosów }\end{array}$ & $\begin{array}{l}\text { Brittle nails/ } \\
\text { Łamliwość } \\
\text { paznokci }\end{array}$ \\
\hline $\begin{array}{l}\text { Vitamin } \mathrm{B}_{12} \\
{[9,26,31] /} \\
\text { Witamina } \mathrm{B}_{12} \\
{[9,26,31]}\end{array}$ & $\begin{array}{l}\text { Lemon-yellow colour of the skin/Cytrynowe zabarwienie } \\
\text { skóry } \\
\text { Skin paleness/Bladość skóry } \\
\text { Hyperpigmentation foci (in approx. I0\% of patients)/ } \\
\text { Ogniska hiperpigmentacji (u ok. 10\% pacjentów) }\end{array}$ & $\begin{array}{l}\text { Pale-yellow mucosa/Bladożótte } \\
\text { błony śluzowe } \\
\text { Glossitis/Zapalenie języka } \\
\text { Cheilitis/Zapalenie czerwieni } \\
\text { wargowej } \\
\text { Stomatitis/Zapalenie jamy ustnej } \\
\text { Ulcerative stomatitis/ } \\
\text { Wrzodziejące zapalenie jamy } \\
\text { ustnej } \\
\text { Painful atrophy of oral and tongue } \\
\text { mucosa/Bolesna atrofia błony } \\
\text { śluzowej jamy ustnej i języka } \\
\text { A tendency for candidiasis/ } \\
\text { Skłonność do infekcji } \\
\text { drożdżakowych } \\
\text { Recurrent aphthae/Nawracające } \\
\text { afty } \\
\text { Burning sensation in the oral } \\
\text { cavity/Uczucie pieczenia jamy } \\
\text { ustnej }\end{array}$ & & \\
\hline $\begin{array}{l}\text { Vitamin C } \\
\text { - deficiency } \\
\text { leads to scurvy } \\
{[9,26,32] /} \\
\text { Witamina C } \\
\text { - niedobór } \\
\text { prowadzi } \\
\text { do rozwoju } \\
\text { szkorbutu } \\
{[9,26,32]}\end{array}$ & $\begin{array}{l}\text { Follicular purpura/Plamica przymieszkowa } \\
\text { PetechiaeNybroczyny } \\
\text { Follicular hyperkeratosis/Hiperkeratoza mieszkowa } \\
\text { Subungual splinter hemorrhage/Linijne wybroczyny } \\
\text { podpaznokciowe przypominające drzazgi } \\
\text { Limb oedema/Obrzęki kończyn } \\
\text { Delayed wound healing/Opóźnienie gojenia ran }\end{array}$ & $\begin{array}{l}\text { Inflammation of gums with } \\
\text { enlarged or swollen gums, } \\
\text { possibly with bleeding and loss } \\
\text { of teeth/Stan zapalny dziąseł } \\
\text { z przerostem lub obrzęiem, } \\
\text { któremu mogą towarzyszyć } \\
\text { krwawienia i utrata zębów } \\
\text { Increased risk of periodontal } \\
\text { infections/Zwiększone ryzyko } \\
\text { infekcji przyzębia } \\
\text { Ulceration of oral mucosa/ } \\
\text { Owrzodzenia błony śluzowej } \\
\text { jamy ustnej } \\
\text { Teeth development disorders in } \\
\text { children/Zaburzenia w rozwoju } \\
\text { zębów u dzieci } \\
\text { Idiopathic bleeding from mucosa/ } \\
\text { Samoistne krwawienia z błony } \\
\text { śluzowej }\end{array}$ & $\begin{array}{l}\text { Corkscrew } \\
\text { hairs/ Włosy } \\
\text { korkociągowe }\end{array}$ & \\
\hline $\begin{array}{l}\text { Vitamin } \mathrm{E} \\
{[25,26,33] /} \\
\text { Witamina } \mathrm{E} \\
{[25,26,33]}\end{array}$ & $\begin{array}{l}\text { Deficiency is associated with production and deposition } \\
\text { of lipofuscin in tissues/Niedobór wiąże się z produkcją } \\
\text { i odkładaniem w tkankach lipofuscyny } \\
\text { Petechiae/Wybroczyny } \\
\text { Hyperkeratotic follicular papule/Hiperkeratotyczne grudki } \\
\text { mieszkowe } \\
\text { Phrynoderma/Frynodermia } \\
\text { Skin paleness/Bladość skóry }\end{array}$ & $\begin{array}{l}\text { Mucosa paleness/Bladość błony } \\
\text { śluzowej }\end{array}$ & & \\
\hline
\end{tabular}


Table I. Cont.

Tabela I. Cd.

\begin{tabular}{|c|c|c|c|c|}
\hline $\begin{array}{l}\text { Vitamins and } \\
\text { microelements/ } \\
\text { Witaminy } \\
\text { i mikroelementy }\end{array}$ & Skin manifestations/Objawy skórne & $\begin{array}{c}\text { Oral and conjunctival } \\
\text { manifestations/Objawy } \\
\text { w obrębie jamy ustej } \\
\text { i spojówek }\end{array}$ & Hair/Włosy & $\begin{array}{c}\text { Nails/ } \\
\text { Paznokcie }\end{array}$ \\
\hline $\begin{array}{l}\operatorname{Zinc}[9,26,34 \\
35,36] / \text { Cynk } \\
{[9,26,34,35} \\
36]\end{array}$ & $\begin{array}{l}\text { Diaper dermatitis/Pieluszkowe zapalenie skóry } \\
\text { Hypersensitivity to light/Nadwrażliwość na światło } \\
\text { Delayed wound healing/Opóźnienie gojenia ran } \\
\text { Blepharitis/Zapalenie brzegów powiek } \\
\text { Dermatitis located in places exposed to pressure and } \\
\text { chronic irritation, such as the area of natural body } \\
\text { orifices and distal parts of the limbs/Zmiany wypryskowe } \\
\text { zlokalizowane w miejscach narażonych na ucisk i przewlekłe } \\
\text { drażnienie, takich jak okolice naturalnych otworów ciała } \\
\text { oraz dystalne części kończyn } \\
\text { Vesicles, blisters, pustules may form within the lesions/ } \\
\text { W obrębie zmian mogą tworzyć się pęcherzyki, pęcherze, } \\
\text { krosty }\end{array}$ & $\begin{array}{l}\text { Cracks, ulcers, erosions of } \\
\text { the oral mucosa/Pęknięcia, } \\
\text { owrzodzenia, nadżerki błony } \\
\text { śluzowej jamy ustnej } \\
\text { Conjunctivitis/Zapalenie } \\
\text { spojówek } \\
\text { Burning mouth syndrome/ } \\
\text { Zespół pieczenia jamy ustnej } \\
\text { Angular cheilitis (early } \\
\text { manifestation)/Zapalenie kącików } \\
\text { ust (wczesny objaw) }\end{array}$ & $\begin{array}{l}\text { Alopecia/ } \\
\text { Łysienie } \\
\text { Delayed } \\
\text { hair growth/ } \\
\text { Spowolnienie } \\
\text { wzrostu } \\
\text { włosów }\end{array}$ & $\begin{array}{l}\text { Delayed } \\
\text { nail growth/ } \\
\text { Spowolnienie } \\
\text { wzrostu } \\
\text { paznokci } \\
\text { Dystrophic } \\
\text { nail plates/ } \\
\text { Dystroficzne } \\
\text { płytki } \\
\text { paznokciowe }\end{array}$ \\
\hline $\begin{array}{l}\text { Copper } \\
{[26,37] / \text { Miedź }} \\
{[26,37]}\end{array}$ & Skin hypopigmentation/Hipopigmentacja skóry & & $\begin{array}{l}\text { Sparse, fine, } \\
\text { breaking, } \\
\text { light-coloured } \\
\text { and brittle } \\
\text { hair/Włosy } \\
\text { rzadkie, } \\
\text { cienkie, } \\
\text { tamliwe, jasne } \\
\text { i kruche } \\
\text { Trichoscopy } \\
\text { shows } \\
\text { primarily pilli } \\
\text { torti, less } \\
\text { frequently } \\
\text { trichorrhexis } \\
\text { nodosa and } \\
\text { monilethrix/ } \\
\text { W trichoskopii } \\
\text { widoczne } \\
\text { są przede } \\
\text { wszystkim } \\
\text { włosy } \\
\text { skręcone, } \\
\text { rzadziej } \\
\text { rozszczep } \\
\text { węzłowaty } \\
\text { włosów } \\
\text { i włosy } \\
\text { paciorkowate }\end{array}$ & \\
\hline $\begin{array}{l}\text { Selenium [38]// } \\
\text { Selen [38] }\end{array}$ & & & & $\begin{array}{l}\text { Leukonychia/ } \\
\text { Leukonychia }\end{array}$ \\
\hline $\begin{array}{l}\text { Calcium [9]/ } \\
\text { Wapń [9] }\end{array}$ & & $\begin{array}{l}\text { Enamel and dentin mineralization } \\
\text { disorders/Zaburzenia } \\
\text { mineralizacji szkliwa i zębiny }\end{array}$ & & \\
\hline $\begin{array}{l}\text { Iron }[9,26, \\
39] / \text { Zelazo } \\
{[9,26,39]}\end{array}$ & $\begin{array}{l}\text { Skin atrophy/Atrofia skóry } \\
\text { Skin paleness/Bladość skóry }\end{array}$ & $\begin{array}{l}\text { Atrophy of oral mucosa/Zanik } \\
\text { błony śluzowej jamy ustnej } \\
\text { Atrophic glossitis/Zanikowe } \\
\text { zapalenie języka } \\
\text { Mucosa paleness/Bladość błony } \\
\text { śluzowej } \\
\text { Angular cheilitis/Zapalenie } \\
\text { kącików ust }\end{array}$ & $\begin{array}{l}\text { Excessive } \\
\text { hair loss/ } \\
\text { Nadmierne } \\
\text { wypadanie } \\
\text { włosów }\end{array}$ & $\begin{array}{l}\text { Pale nails/ } \\
\text { Blade } \\
\text { paznokcie } \\
\text { Koilonychia/ } \\
\text { Koilonychia }\end{array}$ \\
\hline
\end{tabular}


difficult, and sometimes impossible, to distinguish between skin manifestations of the underlying disease and changes caused by therapy. Moreover, some of skin lesions resulting from the pathological process may appear for the first time during the treatment, which further complicates the differential diagnosis [11]. The groups of drugs most commonly used in the treatment of IBD are: corticosteroids, aminosalicylates, immunosuppressants and biological drugs [40].

\section{Glucocorticosteroids}

Corticosteroids are a group of drugs that are very often used in people with IBD, primarily in acute disease flares [40]. Skin lesions are one of the side effects of steroid therapy and may appear during the use of oral, as well as inhaled and topical preparations [41-43]. Systemic treatment with glucocorticosteroids in low doses (not higher than $5 \mathrm{mg}$ of prednisone daily) may cause skin lesions in about $5 \%$ of patients after 1 year of therapy [44]. Among the skin side effects occurring in the course of steroid therapy, there are: burning sensation in the application site, telangiectasia, skin hypopigmentation or hyperpigmentation, rosacea, allergic contact dermatitis, hirsutism, extravasations, increased risk of infection (including opportunistic infections) $[9,41-44]$. Thinning of the skin caused by inhibition of the proliferation of the basal layer keratinocytes, flattening of the rete ridges, a reduction in the amount of ground substance and the size of fibroblasts is another important adverse effect. Moreover, a reduction in the amount of the ground substance causes a loss of support for the vessels, promoting their dilatation and formation of ecchymosis [42]. Long-term therapy with glucocorticosteroids may also lead to the impairment of the epidermal barrier function [44]. Moreover, glucocorticosteroids delay the wound healing process by inhibiting the influx of macrophages to the wound area, which leads to reduction of phagocytosis, reduced secretion of cytokines and growth factors, They also cause the inhibition of collagen synthesis, delay of reepithelialization and formation of capillary networks, and inhibition of fibroblast proliferation [42]. One of the irreversible adverse effects of glucocorticosteroid therapy is the formation of stretch marks. As a result of swelling and inflammation of the dermis, there is a linear deposition of collagen and elastin, and it leads to the formation of scars [42].

\section{Aminosalicylates}

Aminosalicylates are one of the groups of drugs used in the treatment of non-specific IBD, primarily ulcerative colitis. Sulfasalazine, consisting of 5-aminosalicylic acid and sulfanilic acid amide również wystąpić u osób w okresie remisji oraz u pacjentów z umiarkowanym nasileniem choroby [23, 24].

Niedobory witamin oraz mikro- i makroelementów prowadzą do wielu zmian w obrębie skóry, błony śluzowej, włosów i paznokci. W tabeli 1 przedstawiono objawy niedoborów wybranych składników odżywczych [25-39].

\section{ZMIANY SKÓRNE ZWIAZZANE Z LECZENIEM NIESWOISTYCH ZAPALEŃ JELIT}

Liczne zmiany skórne występujące u osób z NZJ są wynikiem zastosowanego leczenia, a odróżnienie manifestacji skórnych choroby podstawowej od zmian wywołanych terapią jest bardzo trudne, a niekiedy niemożliwe. Ponadto część zmian skórnych wynikających z procesu chorobowego może pojawić się po raz pierwszy w trakcie leczenia, co dodatkowo utrudnia diagnostykę różnicową [11]. W terapii NZJ najczęściej stosowane są glikokortykosteroidy, aminosalicylany, leki immunosupresyjne oraz leki biologiczne [40].

\section{Glikokortykosteroidy}

Glikokortykosteroidy są grupą leków bardzo często stosowaną u osób z NZJ, przede wszystkim w ostrych rzutach choroby [40]. Zmiany skórne są jednym z działań niepożądanych glikokortykosteroidoterapii i mogą pojawiać się zarówno podczas stosowania preparatów doustnych, jak i wziewnych oraz miejscowych [41-43]. Leczenie ogólne glikokortykosteroidami w małych dawkach (nie większych niż $5 \mathrm{mg}$ prednizonu na dobę) może powodować wystąpienie zmian skórnych u ok. 5\% pacjentów już po roku terapii [44]. Wśród skórnych działań niepożądanych pojawiających się w przebiegu glikokortykosteroidoterapii wyróżnia się m.in. uczucie pieczenia $\mathrm{w}$ miejscu aplikacji, teleangiektazje, hipopigmentację lub hiperpigmentację skóry, trądzik różowaty, alergiczne kontaktowe zapalenie skóry, hirsutyzm, wylewy krwawe, zwiększone ryzyko infekcji (w tym infekcji oportunistycznych) [9, 41-44]. Ważnym działaniem niepożądanym jest także ścieńczenie skóry spowodowane hamowaniem proliferacji keratynocytów warstwy podstawnej, spłaszczeniem sopli naskórkowych, zmniejszeniem ilości istoty podstawowej oraz wielkości fibroblastów. Ponadto zmniejszenie ilości istoty podstawowej powoduje utratę podpory dla naczyń, co sprzyja ich dylatacji i powstawaniu wylewów krwawych [42]. Długotrwała terapia glikokortykosteroidami może również prowadzić do utraty funkcji bariery naskórkowej [44]. Glikokortykosteroidy opóźniają ponadto proces gojenia ran poprzez hamowanie napływu makrofagów w okolice rany, co prowadzi do ograniczenia fagocytozy oraz zmniejszonego wydzielania cytokin i czynników wzrostu. Powodują one również hamowanie syntezy kolagenu, spowolnienie reepitelializacji i tworzenia 
(sulfapyridine), is broken down in the gastrointestinal tract. Mesalazine (5-aminosalicylic acid) is a breakdown product of sulfasalazine [45-47]. The incidence of skin and mucosal lesions during sulfasalazine therapy in patients with IBD ranges from $0.5 \%$ to $5 \%$. These are mainly drug-induced rashes, photosensitivity, and rarely exfoliative dermatitis [47]. In patients suffering from rheumatoid arthritis skin lesion such as erythema, exfoliation, itching, peeling lips, mouth ulcers, hives and thinning of the hair were also observed. Most side effects are mild and do not require discontinuation of therapy [46-48]. However, cases of serious complications such as Stevens-Johnson syndrome or DRESS (drug reaction with eosinophilia and systemic symptoms) have also been reported [49, 50]. Studies have shown that mesalazine causes significantly fewer adverse effects compared to sulfasalazine, and their severity and clinical significance less frequently lead to discontinuation of the therapy $[45,46]$. However, cases of severe drug reactions to mesalazine have been reported, such as toxic epidermal necrolysis [51], StevensJohnson syndrome [50], and acute generalized pustular eruption [52]. Moreover, both active substances can cause aplastic anaemia in the course of which paleness of skin and mucous membranes, ecchymosis, haemorrhage and an increased risk of skin and mucosal infections are noticed [9]. There are also reports of fixed drug eruption induced by aminosalicylate therapy [53-55]. Lichen planus, lichenoid reactions of the oral mucosa and taste disturbances are also reported [9]. Mesalazine, like sulfasalazine, may also increase sensitivity to light as a result of an idiosyncratic phototoxic reaction, or as a result of photoallergic reaction [56]. In literature there are conflicting reports regarding the effect of mesalazine on hair loss. Netzer reported cases of increased hair loss during therapy, which resolved after drug discontinuation [57], while Shah et al. demonstrated a protective effect of the drug [58].

\section{Immunosuppressive drugs}

Azathioprine, mercaptopurine and methotrexate, and others, are used in the maintenance treatment of non-specific IBD.

The treatment with azathioprine and mercaptopurine rarely causes skin and mucosal changes. One of the adverse effects of these drugs is alopecia, which is sometimes observed during the treatment with methotrexate, as well [59-61]. There are over 20 case reports of azathioprine-induced Sweet's syndrome, accounting for $2 \%$ of all adverse effects of this drug. The vast majority of them occurred in patients treated for IBD [62], which may question the effect of aza- sieci naczyń kapilarnych oraz hamowanie proliferacji fibroblastów [42]. Jednym z nieodwracalnych działań niepożądanych glikokortykosteroidoterapii jest powstawanie rozstępów. W wyniku obrzęku i stanu zapalnego skóry właściwej dochodzi do linearnego odkładania się kolagenu i elastyny oraz powstawania blizn [42].

\section{Aminosalicylany}

Aminosalicylany są jedną z grup leków wykorzystywanych w leczeniu NZJ, przede wszystkim wrzodziejącego zapalenia jelita grubego. Sulfasalazyna, składająca się z kwasu 5-aminosalicylowego oraz amidu kwasu sulfanilowego (sulfapirydyny), ulega rozpadowi w przewodzie pokarmowym. Mesalazyna, czyli kwas 5-aminosalicylowy, jest produktem rozpadu sulfasalazyny [45-47]. Częstość występowania zmian skórnych i śluzówkowych w trakcie terapii sulfasalazyną u chorych z NZJ waha się w zakresie 0,5-5\%. Są to przede wszystkim osutki polekowe, reakcje fotoalergiczne, rzadko złuszczające zapalenie skóry [47]. U pacjentów leczonych z powodu reumatoidalnego zapalenia stawów stwierdzono również występowanie zmian skórnych w postaci rumienia, złuszczania i świądu skóry, złuszczania czerwieni wargowej, owrzodzeń jamy ustnej, bąbli pokrzywkowych oraz ścieńczenia włosów. Większość działań niepożądanych ma charakter łagodny i nie wymaga przerwania terapii [46-48], jednak w piśmiennictwie opisano także przypadki ciężkich powikłań, takich jak zespół Stevensa-Johnsona lub zespół DRESS (drug reaction with eosinophilia and systemic symptoms) $[49,50]$. Badania wykazały, że mesalazyna powoduje znacząco mniej działań niepożądanych $\mathrm{w}$ porównaniu $\mathrm{z}$ sulfasalazyną, a ich nasilenie $\mathrm{i}$ istotność kliniczna rzadziej prowadzi do konieczności odstawienia leku $[45,46]$. Opisano jednak przypadki ciężkich reakcji polekowych po mesalazynie, takich jak toksyczna nekroliza naskórka [51], zespół Stevensa-Johnsona [50] lub ostra uogólniona osutka krostkowa [52]. Ponadto obie substancje czynne mogą powodować anemię aplastyczną, w której przebiegu pojawiają się bladość skóry i błon śluzowych, wybroczyny, wylewy krwawe oraz zwiększone ryzyko infekcji skórnych i śluzówkowych [9]. W piśmiennictwie można znaleźć także opisy przypadków rumienia trwałego indukowanego terapią aminosalicylanami [53-55]. W obrębie błony śluzowej jamy ustnej stwierdza się występowanie liszaja płaskiego, zmian liszajopodobnych oraz zaburzeń smaku [9]. Mesalazyna, podobnie jak sulfasalazyna, może także zwiększać wrażliwość na światło w wyniku idiosynkratycznej reakcji fototoksycznej lub wskutek działania fotouczulającego [56]. W piśmiennictwie istnieją sprzeczne doniesienia dotyczące wpływu mesalazyny na łysienie. Netzer opisał przypadki nasilonej utraty włosów w trakcie terapii, która ustępowała po odstawieniu leku [57], natomiast Shah i wsp. wykazali protekcyjny wpływ preparatu [58]. 
thioprine as the main causative factor, as IBD is an independent risk factor for the development of this dermatosis [19]. However, there were reports of patients treated with azathioprine for reasons other than IBD in whom Sweet's syndrome was diagnosed and confirmed by histopathological examination [62]. An important adverse effect of azathioprine is photosensitivity, that may last from several to several dozens of weeks after the end of treatment [63]. Thiopurines also increase the risk of infection, including infection with opportunistic pathogens, and cancer development [9].

Also, during treatment with methotrexate, skin and mucosal changes of various nature and location may occur. Cutaneous ulcers are rarely reported, primarily in patients receiving treatment for psoriasis. Changes of this type may appear at any stage of the therapy, and their formation results from the high sensitivity of rapidly dividing keratinocytes to the folic acid antagonist. There are also reports of methotrexate-induced photosensitivity, exfoliative dermatitis, Stevens-Johnson syndrome, toxic epidermal necrolysis, and erythema multiforme [64-66]. A number of lesions located in the oral mucosa are also observed, such as erosions, ulcerative stomatitis or mucositis. In addition, there is an increased risk of infection. There have also been cases of dysgeusia in the form of reduced intensity or complete loss of the ability to sense taste [9]. Hand-foot syndrome is usually caused by high doses of chemotherapeutic agents, although it has also been reported after a single low dose of methotrexate. Aetiology of the disorder is not fully understood, but eruptions are probably the result of cytotoxic effects of drugs on epidermal cells. This syndrome is characterized by the presence of well-demarcated, symmetrical erythematous changes, sometimes with blisters and epidermal exfoliation, located on the hands and feet [64].

\section{Biological drugs}

Biological drugs, such as infliximab, adalimumab, vedolizumab, and ustekinumab, are increasingly used in the treatment of non-specific IBD [67-69].

Monoclonal antibodies directed against tumor necrosis factor (infliximab, adalimumab) often provoke the development of adverse effects in the form of skin lesions, presence of which is found in as much as $20-62 \%$ of patients [67]. The most common dermatological complications of the above-mentioned therapy include: xerosis, psoriasis-like dermatitis, eczema and infectious lesions. A rapid response to treatment with topical glucocorticosteroids, frequent bacterial superinfections, no clear demarcation of lesions and a silver-white scales are characteristic of psoriasis-like dermatitis $[67,70]$.

\section{Leki immunosupresyjne}

W leczeniu podtrzymującym NZJ wykorzystywane są m.in. azatiopryna, merkaptopuryna i metotreksat.

Terapia azatiopryną i merkaptopuryną rzadko wywołuje zmiany skórne i śluzówkowe. Jednym z działań niepożądanych tych leków jest łysienie, które niekiedy obserwuje się także w trakcie leczenia metotreksatem [59-61]. W piśmiennictwie można znaleźć ponad 20 opisów przypadków zespołu Sweeta indukowanego azatiopryną, który stanowi $2 \%$ wszystkich działań niepożądanych tego leku. Większość z nich wystąpiła u pacjentów leczonych z powodu NZJ [62], co może podawać w wątpliwość działanie azatiopryny jako głównego czynnika sprawczego, gdyż NZJ są niezależnym czynnikiem ryzyka rozwoju tej dermatozy [19]. Opisano jednak przypadki pacjentów leczonych azatiopryną z innego powodu niż NZJ, u których rozpoznano zespół Sweeta potwierdzony badaniem histopatologicznym [62]. Ważnym efektem niepożądanym azatiopryny jest nadwrażliwość na światło, która utrzymuje się od kilku do kilkunastu tygodni po zakończeniu leczenia [63]. Tiopuryny zwiększają także ryzyko infekcji, w tym patogenami oportunistycznymi, oraz rozwoju nowotworów [9].

W trakcie terapii metotreksatem mogą występować również zmiany skórne i śluzówkowe o zróżnicowanym charakterze i umiejscowieniu. Owrzodzenia zlokalizowane na skórze opisywane są rzadko, przede wszystkim u pacjentów leczonych z powodu łuszczycy. Zmiany tego typu mogą się pojawić na każdym etapie terapii, a ich powstawanie wynika z dużej wrażliwości szybko dzielących się keratynocytów na działanie antagonisty kwasu foliowego. W piśmiennictwie można znaleźć także opisy przypadków indukowanej metotreksatem nadwrażliwości na światło, złuszczającego zapalenia skóry, zespołu Stevensa-Johnsona, toksycznej nekrolizy naskórka oraz rumienia wielopostaciowego [64-66]. Obserwuje się również wiele zmian zlokalizowanych na błonie śluzowej jamy ustnej, takich jak nadżerki, wrzodziejące zapalenie jamy ustnej czy uogólniony stan zapalny błony śluzowej jamy ustnej. Ponadto występuje zwiększone ryzyko infekcji. Stwierdzono także przypadki zaburzeń smaku w postaci zmniejszenia intensywności lub całkowitej utraty zdolności odczuwania smaków [9]. Zespół dłoniowo-podeszwowy zwykle jest wywoływany przez duże dawki chemioterapeutyków, chociaż opisano także przypadek wystąpienia tego rodzaju zmian skórnych po pojedynczej małej dawce metotreksatu. Etiologia schorzenia nie jest w pełni poznana, jednak wykwity są prawdopodobnie wynikiem cytotoksycznego działania leków na komórki naskórka. Zespół ten charakteryzuje się obecnością dobrze odgraniczonych, symetrycznych zmian rumieniowych, niekiedy z obecnością pęcherzy i złuszczania naskórka, które są zlokalizowane na dłoniach i stopach [64]. 
Anti-TNF-a antibodies are drugs widely used not only in the treatment of IBD, but also in the treatment of psoriasis and psoriatic arthritis. There are reports of paradoxical reactions involving development of the above-mentioned disease in patients treated with TNF-a antagonists for IBD [71]. Articular pain caused by the paradoxical reaction in patients with IBD treated with anti-TNF-a antibodies may occur in over $10 \%$ of patients. In addition, adalimumab, used in the treatment of moderate to severe acne inversa, and other TNF-a antagonists may cause hidradenitis suppurativa-type of changes. Some cases of a paradoxical reaction in the form of pyoderma gangrenosum have also been described [72].

TNF- $\alpha$ antagonists also increase the risk of skin infections, both bacterial (mainly staphylococcal and streptococcal), as well as fungal and viral. Most of them appear after 2-3 years of therapy [70]. There is also an increased risk of skin cancers in patients treated with anti-TNF-a antibodies, especially in patients with IBD who ever received thiopurine therapy. Some patients also develop alopecia during treatment. It can be alopecia areata or alopecia secondary to psoriatic lesions and psoriatic dermatitis [67]. Moreover, literature data indicate that anti-TNF-a antibodies are one of the more common causes of drug-induced vasculitis [72]. Other observed cutaneous side effects include skin reactions at the injection site, drug-induced lupus, lichen planus, lymphomas, ulcerations, acne lesions, granuloma annulare, palmoplantar pustulosis, sarcoidosis, dermatomyositis, vitiligo, erythema multiforme, Stevens-Johnson syndrome $[9,67,72,73]$.

Risk factors for the development of cutaneous adverse effects of TNF- $\alpha$ antagonists include the presence of ANA antibodies, young age (<28 years) at the start of therapy, Crohn's disease, higher doses of drugs, and in case of the pediatric population lower faecal calprotectin levels $[67,70]$. An increased risk of developing psoriasis during anti-TNF-a antibodies therapy is postulated in smokers, women, people with a high body mass index (BMI), short duration of IBD and with Crohn's disease. However, the data available in the literature are contradictory, therefore there is a need for further research aimed at identification of risk factors for the development of skin lesions in the course of anti-TNF-a antibodies therapy [67].

Ustekinumab and vedolizumab are drugs having a relatively good safety profile, rarely causing skin and mucosal changes. Ustekinumab is a human monoclonal antibody that inhibits the activity of interleukins 12 and 23. The most common adverse effects of this drug during a long-term therapy (lasting for at least 1 year) are nasopharyngitis, upper respiratory tract infections, headache and skin reactions at the injection site [69]. Single cases of skin lesions

\section{Leki biologiczne}

W leczeniu NZJ coraz częściej wykorzystywane są leki biologiczne, takie jak infliksymab, adalimumab, wedolizumab i ustekinumab [67-69].

Przeciwciała monoklonalne skierowane przeciwko czynnikowi martwicy nowotworów (infliksymab, adalimumab) często prowokują występowanie działań niepożądanych w postaci zmian skórnych, które stwierdza się nawet u 20-62\% pacjentów [67]. Do najczęstszych powikłań skórnych powyższej terapii należą kseroza, łuszczycopodobne zapalenie skóry, zmiany wypryskowe oraz infekcyjne. Charakterystyczna dla łuszczycopodobnego zapalenia skóry jest szybka odpowiedź na leczenie miejscowymi preparatami glikokortykosteroidowymi, częste nadkażenia bakteryjne, brak wyraźnego odgraniczenia zmian i srebrzystobiałej łuski $[67,70]$.

Przeciwciała anty-TNF-a są lekami szeroko stosowanymi nie tylko w leczeniu NZJ, lecz także łuszczycy i łuszczycowego zapalenia stawów. W piśmiennictwie można znaleźć opisy przypadków reakcji paradoksalnych polegających na rozwoju wyżej wymienionych jednostek chorobowych u pacjentów leczonych antagonistami TNF-a z powodu NZJ [71]. Dolegliwości bólowe stawów wywołane reakcją paradoksalną u chorych z NZJ poddanych terapii przeciwciałami anty-TNF-a mogą dotyczyć ponad 10\% pacjentów. Ponadto adalimumab wykorzystywany w terapii umiarkowanego i ciężkiego hidradenitis suppurativa oraz inni antagoniści TNF-a mogą powodować zmiany w postaci hidradenitis suppurativa. Opisano również przypadki reakcji paradoksalnej w postaci piodermii zgorzelinowej [72].

Antagoniści TNF-a zwiększają także ryzyko infekcji skórnych, zarówno bakteryjnych (przede wszystkim gronkowcowych i paciorkowcowych), jak i grzybiczych oraz wirusowych. Większość z nich pojawia się po ok. 2-3 latach terapii [70]. Stwierdzono również podwyższone ryzyko rozwoju raków skóry u chorych leczonych przeciwciałami anty-TNF-a, szczególnie u pacjentów z NZJ poddanych terapii tiopurynami. U części pacjentów w trakcie leczenia występuje także łysienie. Może to być łysienie plackowate lub łysienie w przebiegu zmian łuszczycowych oraz łuszczycopodobnego zapalenia skóry [67]. Dane z piśmiennictwa wskazują ponadto, że przeciwciała anty-TNF-a są jedną z częstszych przyczyn polekowych zapaleń naczyń [72]. Pozostałe obserwowane skórne działania niepożądane to m.in. odczyny skórne w miejscu wkłucia, zmiany typu tocznia polekowego, liszaj płaski, chłoniaki, owrzodzenia, zmiany trądzikowe, ziarniniak obrączkowaty, krostkowica dłoni i stóp, sarkoidoza, zapalenie skórno-mięśniowe, bielactwo, rumień wielopostaciowy, zespół Stevensa-Johnsona [9, $67,72,73]$.

Wśród czynników ryzyka wystąpienia skórnych efektów ubocznych antagonistów TNF-a wymienia się obecność przeciwciał ANA, młody wiek (<28 lat) w momen- 
caused by ustekinumab have been reported, such as subacute cutaneous lupus erythematosus [74], urticarial reactions [75] or leukocytoclastic vasculitis [76]. Due to its mechanism of action, it is often successfully used in the treatment of paradoxical reactions caused by anti-TNF-a antibodies. However, there are reports of exacerbation of skin lesions in the course of pustular psoriasis and exacerbation of psoriatic arthritis symptoms caused by ustekinumab [69, 72, 77]. Vedolizumab is a humanized IgG1 monoclonal antibody directed against the $\alpha 4 \beta 7$ integrin antigen. Due to its selective action on the intestinal vascular epithelium, this drug is considered very safe. There are reports of exacerbation of skin lesions in the course of pyoderma gangrenosum and nodular vasculitis occurring after switching to vedolizumab, which probably results from insufficient drug efficacy in the treatment of extraintestinal manifestations $[68,78]$. A case of Sweet's syndrome has also been reported, the symptoms of which appeared 24 hours after the first dose of vedolizumab [79]. Pharyngitis is a common adverse effect of the drug [9].

\section{CONCLUSIONS}

The skin performs important functions for the entire system, not only protecting internal organs against the influence of the external environment, but also exercising immunological supervision over a number of defense processes. Often its clinical condition and characteristic changes reflect pathologies of internal organs, including non-specific IBD. Skin eruptions not only may coexist with IBD, but they can often precede intestinal symptoms. Knowing them may contribute to the correct diagnosis and early implementation of appropriate therapy.

\section{CONFLICT OF INTEREST}

The authors declare no conflict of interest. cie rozpoczęcia terapii, chorobę Leśniowskiego-Crohna, wyższe dawki leków oraz w populacji dziecięcej niższe stężenie kalprotektyny w kale $[67,70]$. Sugeruje się zwiększone ryzyko rozwoju łuszczycy w trakcie terapii przeciwciałami anty-TNF-a u palaczy, kobiet, osób z wysokim wskaźnikiem masy ciała (body mass index - BMI), krótkim czasem trwania NZJ oraz z chorobą Leśniowskiego-Crohna. Dostępne w piśmiennictwie dane są jednak sprzeczne, dlatego konieczne jest prowadzenie dalszych badań mających na celu zidentyfikowanie czynników ryzyka występowania zmian skórnych w przebiegu terapii przeciwciałami anty-TNF-a [67].

Ustekinumab i wedolizumab są lekami o relatywnie dobrym profilu bezpieczeństwa, rzadko wywołującymi zmiany skórne i śluzówkowe. Ustekinumab jest ludzkim przeciwciałem monoklonalnym hamującym aktywność interleukin 12 i 23. Najczęstsze działania niepożądane tego leku podczas długotrwałej terapii (co najmniej rok leczenia) to zapalenie części nosowej gardła, infekcje górnych dróg oddechowych, bóle głowy i odczyny skórne w miejscu podania preparatu [69]. W piśmiennictwie opisano pojedyncze przypadki zmian skórnych spowodowanych przez ustekinumab, takie jak podostra postać skórna tocznia rumieniowatego [74], reakcje pokrzywkowe [75] i leukocytoklastyczne zapalenie naczyń [76]. Ze względu na mechanizm działania lek często $\mathrm{z}$ powodzeniem wykorzystuje się $\mathrm{w}$ leczeniu reakcji paradoksalnych wywołanych przeciwciałami anty-TNF-a. Można jednak znaleźć opisy przypadków zaostrzenia zmian skórnych w przebiegu łuszczycy krostkowej oraz nasilenia dolegliwości łuszczycowego zapalenia stawów spowodowanych działaniem ustekinumabu [69, 72, 77]. Wedolizumab jest humanizowanym przeciwciałem monoklonalnym klasy IgG1 skierowanym przeciwko antygenowi a4 $\beta 7$ integryny. Ze względu na selektywne działanie na nabłonek naczyń jelit lek ten uważany jest za bardzo bezpieczny. W piśmiennictwie przedstawiono opisy przypadków zaostrzenia zmian skórnych w przebiegu piodermii zgorzelinowej oraz guzkowego zapalenia naczyń po zmianie terapii na wedolizumab, co prawdopodobnie wynika z jego niewystarczającej skuteczności w leczeniu manifestacji pozajelitowych [68, 78]. Opisano także przypadek zespołu Sweeta, którego objawy pojawiły się po 24 godzinach od podania pierwszej dawki wedolizumabu [79]. Jednym z często występujących efektów niepożądanych tego leku jest zapalenie gardła [9].

\section{WNIOSKI}

Skóra pełni nadzór immunologiczny nad szeregiem procesów obronnych. Niejednokrotnie jej stan kliniczny i charakterystyczne zmiany odzwierciedlają patologie narządów wewnętrznych, w tym NZJ. Wykwity skórne nie tylko mogą współistnieć z NZJ, ale często poprzedzają objawy jelitowe. Ich znajomość może się 
przyczyniać do prawidłowej diagnostyki i wdrożenia wczesnej terapii.

\section{KONFLIKT INTERESÓW}

Autorki nie zgłaszają konfliktu interesów.

\section{References}

\section{Piśmiennictwo}

1. Weizman A., Huang B., Berel D., Targan S.R., Dubinsky M., Fleshner P., et al.: Clinical, serologic, and genetic factors associated with pyoderma gangrenosum and erythema nodosum in inflammatory bowel disease patients. Inflamm Bowel Dis 2014, 20, 525-533.

2. Ciccacci C., Biancone L., Di Fusco D., Ranieri M., Condino G., Giardina E., et al.: TRAF3IP2 gene is associated with cutaneous extraintestinal manifestations in inflammatory bowel disease. J Crohns Colitis 2013, 7, 44-52.

3. Roth N., Biedermann L., Fournier N., Butter M., Vavricka S.R., Navarini A.A., et al.: Occurrence of skin manifestations in patients of the Swiss Inflammatory Bowel Disease Cohort Study. PLoS One 2019, 14, e0210436.

4. Ampuero J., Rojas-Feria M., Castro-Fernandez M., Cano C., Romero-Gomez M.: Predictive factors for erythema nodosum and pyoderma gangrenosum in inflammatory bowel disease. J Gastroenterol Hepatol 2014, 29, 291-295.

5. Vide J., Osório F., Costa-Silva M., Lopes S., Azevedo F., Camila Dias C., et al.: Cutaneous morbidity among inflammatory bowel disease patients: a cohort study. J Crohns Colitis 2018, 12, 442-451.

6. Rożalski M.: Extraintestinal Crohn's disease (metastatic Crohn's disease). Dermatol Rev 2014, 101, 418-422.

7. Eames T., Landthaler M., Karrer S.: Crohn's disease: an important differential diagnosis of granulomatous skin diseases. Eur J Dermatol 2009, 19, 360-364.

8. Greuter T., Navarini A., Vavricka S.R.: Skin manifestations of inflammatory bowel disease. Clin Rev Allergy Immunol 2017, 53, 413-427.

9. Muhvić-Urek M., Tomac-Stojmenović M., Mijandrušić-Sinčić B.: Oral pathology in inflammatory bowel disease. World J Gastroenterol 2016, 22, 5655-5667.

10. Kyriakou G., Gkermpesi M., Thomopoulos K., Marangos M., Georgiou S.: Metastatic vulvar Crohn's disease preceding intestinal manifestations: a case report and short review. Acta Dermatovenerol Alp Pannonica Adriat 2019, 28, 131-133.

11. Gravina A., Federico A., Ruocco E., Lo Schiavo A., Romano F., Miranda A., et al.: Crohn's disease and skin. United European Gastroenterol J 2016, 4, 165-171.

12. Moravvej H., Razavi G.M., Farshchian M., Malekzadeh R.: Cutaneous manifestations in 404 Iranian patients with inflammatory bowel disease: a retrospective study. Indian J Dermatol Venereol Leprol 2008, 74, 607-610.

13. Faulkes R.E.: Upper limb erythema nodosum: the first presentation of Crohn's disease. Clin Case Rep 2014, 2, 183-185.

14. Annese V.: A review of extraintestinal manifestations and complications of inflammatory bowel disease. Saudi J Med Med Sci 2019, 7, 66-73.

15. Orchard T.R., Chua C.N., Ahmad T., Cheng H., Welsh K.I., Jewell D.P.: Uveitis and erythema nodosum in inflammatory bowel disease: clinical features and the role of HLA genes. Gastroenterology 2002, 123, 714-718.

16. Starba A., Chowaniec M., Wiland P.: Erythema nodosum - presentation of three cases. Reumatologia 2016, 54, 83-85.

17. Alavi A., French L.E., Davis M.D., Brassard A., Kirsner R.S.: Pyoderma gangrenosum: an update on pathophysiology, diagnosis and treatment. Am J Clin Dermatol 2017, 18, 355-372.

18. Wallach D., Vignon-Pennamen M.D.: Pyoderma gangrenosum and Sweet syndrome: the prototypic neutrophilic dermatoses. Br J Dermatol 2018, 178, 595-602.

19. dos Santos Lima C., Pinto R.D.B., de Oliveira Góes H.F., de Abreau Neves Salles S., Vilar E.A.G., Lima C. dos Santos Lima C.: Sweet's syndrome associated with Crohn's disease. An Bras Dermatol 2017, 92, 263-265.

20. Nestor L.A., Tobin A.M.: Oral Sweet's syndrome occurring in ulcerative colitis. BMJ Case Rep 2017, 15, 2017.

21. Hagen J.W., Swoger J.M., Grandinetti L.M.: Cutaneous manifestations of Crohn disease. Dermatol Clin 2015, 33, 417-431.

22. Lankarani K.B.: Oral manifestation in inflammatory bowel disease: a review. World J Gastroenterol 2013, 19, 8571-8579.

23. Casanova M.J., Chaparro M., Molina B., Merino O., Batanero R., Dueñas-Sadornil C., et al.: Prevalence of malnutrition and nutritional characteristics of patients with inflammatory bowel disease. J Crohns Colitis 2017, 11, 1430-1439.

24. Triantafillidis J.K., Vagianos C., Papalois A.E.: The role of enteral nutrition in patients with inflammatory bowel disease: current aspects. Biomed Res Int 2015, 2015, 197167.

25. Cobos G., Cornejo C., McMahon P.: A case of phrynoderma in a patient with Crohn's disease. Pediatr Dermatol 2015, 32, 234236.

26. DiBaise M., Tarleton S.M.: Hair, nails, and skin: differentiating cutaneous manifestations of micronutrient deficiency. Nutr Clin Pract 2019, 34, 490-503.

27. De Oliveira Alves A., Bortolato T., Bernardes Filho F.: Pellagra. J Emerg Med 2018, 54, 238-240.

28. Savvidou S.: Pellagra: a non-eradicated old disease. Clin Pract 2014, 4, 637.

29. NIH Office of Dietary Supplements. Biotin: Fact sheet for health professionals. 2018. Available at: https://ods.od.nih.gov/ factsheets/ Biotin-HealthProfessional/. Accessed January 15, 2019.

30. Patel D.P., Swink S.M., Castelo-Soccio L.: A review of the use of biotin for hair loss. Skin Appendage Disord 2017, 3, 166-169.

31. Green R., Datta Mitra A.: Megaloblastic anemias: nutritional and other causes. Med Clin North Am 2017, 101, 297-317. 
32. González-Sabín M., Rodríguez-Díaz E., Mallo-García S., Astola-Hidalgo I.: Scurvy: an “almost” forgotten disease. Eur J Dermatol 2017, 27, 539-540.

33. Dror D.K., Allen L.H.: Vitamin E deficiency in developing countries. Food Nutr Bull 2011, 32, 124-143.

34. NIH Office of Dietary Supplements. Zinc: Fact sheet for health professionals. 2018. Available at: https://ods.od.nih.gov/factsheets/Zinc-HealthProfessional/. Accessed January 15, 2019.

35. Galimberti F., Mesinkovska N.A.: Skin findings associated with nutritional deficiencies. Cleve Clin J Med 2016, 83, 731-739.

36. Ogawa Y., Kawamura T., Shimada S.: Zinc and skin biology. Arch Biochem Biophys 2016, 611, 113-119.

37. Ghosh S., Chaudhuri S.: Menkes kinky hair syndrome: a case report. Dermatol Online J 2012, $18,4$.

38. Hasunuma N., Umebayashi Y., Manabe M.: True leukonychia in Crohn disease induced by selenium deficiency. JAMA Dermatol 2014, 150, 779-780.

39. Percy L., Mansour D., Fraser I.: Iron deficiency and iron deficiency anaemia in women. Best Pract Res Clin Obstet Gynaecol 2017, 40, 55-67.

40. Vatn M.H., Sandvik A.K.: Inflammatory bowel disease. Scand J Gastroenterol 2015, 50, 748-762.

41. Tashkin D.P., Murray H.E., Skeans M., Murray R.P.: Skin manifestations of inhaled corticosteroids in COPD patients: results from Lung Health Study II. Chest 2004, 126, 1123-1133.

42. Poetker D.M., Reh, D.D.: A comprehensive review of the adverse effects of systemic corticosteroids. Otolaryngol Clin North Am 2010, 43, 753-768.

43. Mehta A.B., Nadkarni N.J., Patil S.P., Godse K.V., Gautam M., Agarwal S.: Topical corticosteroids in dermatology. Indian Dermatol Venereol Leprol 2016, 82, 371-378.

44. Oray M., Abu Samra K., Ebrahimiadib N., Meese H., Foster C.S.: Long-term side effects of glucocorticoids. Expert Opin Drug Saf 2016, 15, 457-465.

45. Sehgal P., Colombel J.F., Aboubakr A., Narula N.: Systematic review: safety of mesalazine in ulcerative colitis. Aliment Pharmacol Ther 2018, 47, 1597-1609.

46. Di Paolo M.C., Paoluzi O.A., Pica R., Iacopini F., Crispino P., Rivera M., et al.: Sulphasalazine and 5-aminosalicylic acid in long-term treatment of ulcerative colitis: report on tolerance and side-effects. Dig Liver Dis 2001, 33, 563-569.

47. Watkinson G.: Sulphasalazine: a review of 40 years' experience. Drugs 1986, 32 Suppl 1, 1-11.

48. Farr M., Scott D.G.I., Bacon P.A.: Side effect profile of 200 patients with inflammatory arthritides treated with sulphasalazine. Drugs 1986, 32, 49-53.

49. Teo L., Tan E.: Sulphasalazine-induced DRESS. Singapore Med J 2006, 47, 237-239.

50. Xiong H., Chen S., Luo X.: Salazosulphapyridine-related Stevens-Johnson syndrome caused by sulphapyridine and confirmed by enzyme-linked immunospot assay. J Crohns Colitis 2018, 12, 381-382.

51. Fukunaga K., Ohda Y., Inoue T., Kono T., Miwa H., Matsumoto T.: Toxic epidermal necrosis associated with mesalamine in a patient with ulcerative colitis. Inflamm Bowel Dis 2007, 13, 1055-1056.

52. Rocci E., Park K., Hutchens K., Winterfield L.: First report of mesalamine (5-aminosalicylic acid) as the causative agent in a case of acute generalized exanthamous pustulosis. Dermatol Online J 2017, 23, 13030/ qt7046n97m.

53. Kanwar A.J., Singh M., Yunus M., Belhaj M.S.: Fixed eruption to sulphasalazine. Dermatologica 1987, $174,104$.

54. Kawada A., Kobayashi T., Noguchi H., Hiruma M., Iishibashi A., Marshall J.: Fixed drug eruption induced by sulfasalazine. Contact Dermatitis 1996, 34, 155-156.

55. Salman A., Seckin Gencosmanoglu D., Alahdab Y.O., Giménez-Arnau A.M.: Mesalazine-induced bullous fixed drug eruption. Contact Dermatitis 2018, 79, 34-35.

56. Cozzani E., Pappalardo F., Gallo R., Parodi A.: photosensitivity induced by mesalazine: report of a case. Am J Gastroenterol 2014, 109, 923-924.

57. Netzer P.: Diffuse alopecia as side effect of mesalazine therapy in Crohn's disease. Schweiz Med Wochenschr 1995, 125, 24382442.

58. Shah R., Abraham B., Hou J., Sellin J.: Frequency and associated factors of hair loss among patients with inflammatory bowel disease. World J Gastroenterol 2015, 21, 229-232.

59. Sonthalia S., Daulatabad D.: Azathioprine-associated anagen effluvium. Indian J Dermatol Venereol Leprol 2016, 82, $322-324$.

60. Anisha S., Sukhjot K., Sunil G.K., Sandeep P.: Bird's Nest View from a Dermatologist's Eye. Int J Trichol 2016,8 , 1-4.

61. Ugajin T., Miyatani H., Demitsu T., Iwaki T., Ushimaru S., Nakashima Y., et al.: Severe myelosuppression following alopecia shortly after the initiation of 6-mercaptopurine in a patient with Crohn's disease. Intern Med 2009, 48, 693-695.

62. McNally A., Ibbetson J., Sidhu S.: Azathioprine-induced Sweet's syndrome: a case series and review of the literature. Australas J Dermatol 2017, 58, 53-57.

63. Hofbauer G.F., Attard N.R., Harwood C.A., McGregor J.M., Dziunycz P., Iotzova-Weiss G., et al.: Reversal of UVA skin photosensitivity and DNA damage in kidney transplant recipients by replacing azathioprine. Am J Transplant 2012, 12, 218-225.

64. Gupta A., Sardana K., Bhardwaj M., Singh A.: Methotrexate cutaneous toxicity following a single dose of $10 \mathrm{mg}$ in a case of chronic plaque psoriasis: a possible idiosyncratic reaction. Indian Dermatol Online J 2018, 9, 328-330.

65. Lewis H.A., Nemer K.M., Chibnall R.J., Musiek A.C.: Methotrexate-induced cutaneous ulceration in 3 nonpsoriatic patients: report of a rare side effect. JAAD Case Rep 2017, 3, 236-239.

66. Weidmann A., Foulkes A.C., Kirkham N., Reynolds N.J.: Methotrexate toxicity during treatment of chronic plaque psoriasis: a case report and review of the literature. Dermatol Ther 2014, 4, 145-156.

67. Segaert S., Hermans C.: Clinical signs, pathophysiology and management of cutaneous side effects of anti-tumor necrosis factor agents. Am J Clin Dermatol 2017, 18, 771-787.

68. Yeh J.E., Tsiaras W.G.: Intractable pyoderma gangrenosum in a Crohn's disease patient on vedolizumab. JAAD Case Rep 2017, 3, 110-112.

69. López-Ferrer A., Laiz A., Puig L.: The safety of ustekinumab for the treatment of psoriatic arthritis. Expert Opin Drug Saf 2017, $16,733-742$. 
70. Fréling E., Baumann C., Cuny J.F., Bigard M.A., Schmutz J.L., Barbaud A., et al.: Cumulative incidence of, risk factors for and outcome of dermatological complications of anti-TNF therapy in inflammatory bowel disease: a 14-year experience. Am J Gastroenterol 2015, 110, 1186-1196.

71. Olteanu R, Zota A.: Paradoxical reactions induced by tumor necrosis factor-alpha antagonists: a literature review based on 46 cases. Indian J Dermatol Venereol Leprol 2016, 82, 7-12.

72. Puig L.: Paradoxical reactions: anti-tumor necrosis factor alpha agents, ustekinumab, secukinumab, ixekizumab, and others. Curr Probl Dermatol 2018, 53, 49-63.

73. Baumgart D.C., Grittner U., Steingraber A., Azzaro M., Philipp S.: Frequency, phenotype, outcome, and therapeutic impact of skin reactions following initiation of adalimumab therapy: experience from a consecutive cohort of inflammatory bowel disease patients. Inflamm Bowel Dis 2011, 17, 2512-2520.

74. Tierney E., Kirthi S., Ramsay B., Ahmad K.: Ustekinumab-induced subacute cutaneous lupus. JAAD Case Rep 2019, 5, $271-273$.

75. Chu C.H., Davis C.: Urticarial reaction to ustekinumab during the treatment of plaque psoriasis in a hepatitis C-positive patient. Drug Saf Case Rep 2017, 4, 9.

76. Costa-Moreira P., Lopes S., Santos A.L., Pedrosa A.F., Andrade P., Portugal R., et al.: Leukocytoclastic vasculitis related to ustekinumab in a Crohn's disease patient: first case report and literature review. J Crohns Colitis 2020, 14, $274-276$.

77. Hay R.A.S., Pan J.Y.: Paradoxical flare of pustular psoriasis triggered by ustekinumab, which responded to adalimumab therapy. Clin Exp Dermatol 2014, 39, 751-752.

78. Pouldar D., Elsensohn A., Ortenzio F., Shiu J., McLeod M., de Feraudy S.: Nodular vasculitis in a patient with Crohn's disease on vedolizumab. Am J Dermatopathol 2018, 40, e36-e37.

79. Martinez Andrés B., Sastre Lozano V., Sánchez Melgarejo J.F:. Sweet syndrome after treatment with vedolizumab in a patient with Crohn's disease. Rev Esp Enferm Dig 2018, 110, 530.

Received: 21.04 .2020

Accepted: 9.06.2020

Otrzymano: $21.04 .2020 \mathrm{r}$.

Zaakceptowano: $9.06 .2020 \mathrm{r}$.

How to cite this article

Hołdrowicz A., Woźniacka A.: Dermatological changes associated with non-specific inflammatory bowel diseases - Crohn's disease and ulcerative colitis. Dermatol Rev/Przegl Dermatol 2020, 107, 332-348, DOI: https://doi.org/10.5114/dr.2020.99878. 